\title{
Politicisation of Regional Authorities and Its Impact on the Development of Civil Society in Slovakia
}

\author{
Upartyjnienie władz regionalnych i jego wpływ na rozwój społeczeństwa \\ obywatelskiego na Słowacji
}

\section{- Abstract •}

The paper is an attempt to answer the question to what extent the local government at the regional level in Slovakia is dominated by political parties, and to what extent by independent politicians. The subject of the study are the results of the 2017 local government elections at the regional level and their analysis. The main goal of the paper is to provide a comprehensive, statisti$\mathrm{cal}$ and comparative presentation of the regional election results in Slovakia and show the degree of local authorities' party-dependency. The secondary objective is to examine how the politicisation of local government influences the development of civil society. An attempt is also made to determine how political competition at the local government level looks like, and whether local entities effectively compete with political parties.

\section{- Abstrakt •}

Artykuł stanowi próbę odpowiedzi na pytanie, w jakim stopniu władza samorządowa na poziomie regionalnym na Słowacji jest płaszczyzną dominacji partii politycznych, a w jakim polityków bezpartyjnych. Przedmiotem badań są wyniki wyborów samorządowych na poziomie regionalnym z 2017 roku i ich analiza. Celem głównym artykułu jest kompleksowe, statystyczno-komparatystyczne przedstawienie wyników wyborów na szczeblu regionalnym na Słowacji oraz ukazanie stopnia upartyjnienia samorządów. Celem drugiego rzędu jest zbadanie, w jaki sposób na rozwój społeczeństwa obywatelskiego wpływa upolitycznienie samorządu terytorialnego. Autorka stara się również ustalić, w jaki sposób przebiega rywalizacja polityczna na poziomie samorządowym i czy lokalne podmioty skutecznie współzawodniczą z partiami politycznymi.

* The article was created as a result of the research project No. 2020/04/X/HS5/00186 financed by the National Science Center, Poland. 
Keywords: politicisation; party-dependency; local government; civil society; political parties; Slovakia
Słowa kluczowe: upartyjnienie samorządu terytorialnego; samorząd terytorialny; społeczeństwo obywatelskie; partie polityczne; Słowacja

\section{Introduction}

Local government reforms in Slovakia, since the establishment of the municipal and regional self-government, have resulted from the process of decentralisation of state power and the development of a democratic state (Barański \& Czyż, 2005, p. 380). At the local level, we see two types of political actors in the struggle for power - political parties and non-party/independent local groups. Political parties are organizations that try to influence national/local policy by winning political offices and represent a wide spectrum of interests of social groups supporting them (Ware, 1996, p. 5). Civil society is characterised by competition and membership in political parties, which gives an opportunity for collective social activity and joint action.

On the other hand, the goal of independent local groups is to implement exclusively local projects, such as raising the inhabitants' standard of living, without aspirations to exercise power over the whole country. Defining the concepts of party and non-party candidates in relation to politicians creates many interpretation problems. Generally speaking, party candidates are politicians who are members of a given political party, put forward by the election committee of that party (Kancik-Kołtun, 2017a, p. 43). As for the notion of non-party politicians, researchers propose two definitions here. According to the first one, non-party politicians do not belong to any political party, regardless of which election committee nominates them as candidates. The second one defines non-party politicians as candidates fielded by a non-party electoral committee, regardless of whether they are party members or not (Gendźwiłł \& Żółtak, 2012, p. 107).

The special role of local government as an entity that inspires citizens' activity, its position in the mission of shaping social order based on social ties, joint actions, invention and initiatives of local communities, should be a leitmotiv for working out collective agreements on solving common social problems (Sasinowski, 2012, p. 31). At the level of local democracy, participation is very important, and by that one should understand personal interactions of inhabitants of a given territorial unit, where the interests, goals, plans and assumptions are combined to improve the quality of life of residents, to solve local issues and meet the needs of the local community (Kancik-Kołtun, 2017b, p. 99). Unfortunately, Slovakia has 
a problem with activating citizens during regional elections, as proved by a low voter turnout, which does not exceed 30\%. Since the beginning of the decentralisation, the election turnout in Slovakia has been at the lowest level in comparison with other countries belonging to the Visegrad Group. Voter turnout reflects the state of civil society.

\section{Methods}

The main subject of the research presented in this publication is the impact of the party-dependency of local government on the development of civil society. The problem defined in this way determines two areas, the exploration of which will shed more light on the multifaceted problem. The first one concerns local government, and more specifically its functioning, local elections and politicisation. The second one focuses on civil society, or more precisely - the development of civil society and factors influencing it.

The exploration of source social research allows us to present a new, previously unexplored topic of using the party-dependency of local government for the development of information society. With the help of another goal, which is the description of social research, we will present the current political status of local government and civil society. Finally, an attempt will be made to explain in what state civil society in Slovakia is nowadays and how the politicisation of local governments affects it. The development and the functioning of civil society is a social matter, and many of the issues raised constitute specific social problems.

This publication concentrates on the question of what role the party-dependency of local government plays in the development and functioning of civil society. Therefore, we tried to find out to what extent local governments are politicised and what factors influence the state of civil society. Thus posed research problems made it possible to present research hypotheses. The main hypothesis suggests that a high level of the politicisation of local government may play a dominant role in the condition of contemporary civil society in Slovakia.

During the research, the existing data were first and foremost examined (election results, voter turnout). Besides, while performing a statistical and comparative analysis of the results of the 2017 regional elections in Slovakia, we tried to investigate the degree of local government's party-dependency. 


\section{Civil Society}

Post-communist history is part of the global phenomenon of the fall of communism and the transformation of democracy. At the beginning of the 1990s, the principles of democracy and free market enjoyed greater support in post-communist countries than in the West, where optimistic reflections awaited the flourishing of active society, the vision which never came true (Císař, Linek, \& Vráblíkova, 2017). In the case of Slovakia, we can talk about the formation and development of civil society only after 1989, because earlier, in the period of real socialism, this development was halted. The pillars of civil society are: well-established democratic attitudes (fostered after 1989); developed local government; civic activity (cooperation for local communities, self-organization); social organizations; and free media.

At present, the term 'society' denotes a dynamic and constantly changing system that is capable of adapting its structure not only to stimuli received from the environment but also sent to it (Gbúrová et al., 2015a, p. 5). The creation of civil society is a long-term and multi-level process, whose basic building block is the citizen (Gbúrová et al., 2015b, p. 13). There are many definitions of "civil society", which is now associated with the political and social order of the democratic system. One definition says: "Civil society is an area separated from the state, economy and private life, in which citizens voluntarily and autonomously establish associations, foundations, movements and unions oriented at expressing, defending and fulfilling their needs and aspirations. Furthermore, any informal activities undertaken for the benefit of the local community are civil" (Szymczak, 2007, pp. 28-29).

As many researchers note, civil society cannot exist without its active citizens. "No civil society exists without them. In a state where citizens are passive or forced to pretend to carry out civil actions, you cannot speak of a true civil society. Therefore, civil activities are understood as citizens' activities focused on administration and public affairs" (Frič, 2016, p. 13).

Civic participation cannot be limited to voter turnout only, so it is important to distinguish: a) political activity based on individual initiative, such as running for elections; b) protest activities (demonstrations, strikes, boycotts, rallies); c) joining mass civil activities (e.g., charity collections, petitions); d) joining the public debate and solving social problems (Bútora, Bútorová, \& Strečanský, 2012, p. 70).

Undoubtedly, civil society has experienced dynamic changes for over 30 years, but it is developing very slowly now. As researchers note, the lack of up-to-date hard statistics on civil society allows for neither additional comparisons between some internal characteristics of civil society, nor comparisons between the civil so- 
ciety sector and other socio-economic partners (Strečanský, 2015, p. 102). The latest data on this subject from 2019 indicate that in Slovakia only $7.9 \%$ of people are employed in the third sector, and thus it is the lowest result in the entire European Union (2019 Report on the State..., 2020, p. 11).

On the other hand, Slovak citizens have been active in social manifestations. At the end of 2011, some associations and professional organizations were mobilised to defend their rights and participate in public protests and strikes (doctors, teachers). Public protests caused by the Gorilla scandal effectively mobilised citizens' activity. These demonstrations were triggered by the publication of the tapes recorded by the Slovak special services - Gorilla, which revealed one of the largest corruption scandals in Central Europe. This scandal showed the procedures for buying and selling laws, state-owned enterprises, hospitals, privatisations. Those participating in it were influential businessmen, government officials and politicians (Krajniak, 2015, pp. 170-177).

The next wave of demonstrations took place a few years later and also concerned political corruption and the mafia. On February 25, 2018, the corpses of the investigative journalist Ján Kuciak and his fiancée Martina Kušnírová were found. The journalist worked on finding out links between the Italian mafia and corruption in Slovakia. His murder caused a wave of protests throughout the country and had its political consequences, including the resignation of the Prime Minister of the Slovak Government Robert Fico. As a result, a significant part of society ceased to trust the authorities. This event significantly affected the state of civil society. One of Kuciak's earlier performances, recorded and posted on YouTube, had a banner in the background with the inscription "Nadácia otvorenej spoločnosti" (Open Society Foundation) - the foundation was set up by George Soros, supporting non-governmental organizations. The American billionaire of Jewish origin was declared the main enemy by Prime Minister Robert Fico. In his opinion, Soros intended to cause a political crisis and prepare a coup d'état. The whole event had a negative impact on civil society, as many citizens were discouraged from NGOs: civil society organizations (CSOs) and those participating in the demonstrations were depicted as foreign agents who wanted to lead to a coup d'état, and disinformation spread throughout the state. The development of the civil society in Slovakia has encountered considerable political pressure, but its growth is still possible through involved activists, as NGOs are protected by administrative law and practice. A glimmer of hope for regaining the image and reputation by civil society organizations is undoubtedly the election of the new, first female president of Slovakia Zuzana Čaputová in 2019 - a lawyer and a social activist who expressed a desire to cooper- 
ate with the government and civil society organizations. The doubts about CSOs' financing indubitably remain their serious problem.

Corruption underlying both events that brought about social demonstration activity seems to be a major issue in Slovakia. Officials as well as local and parliamentary politicians were involved in such corrupt practices as: bribery, paid protection, and active paid protection, that is, trade of influence and abuse of power.

According to the world corruption index of 2019, Slovakia ranks $59^{\text {th }}$ out of 195 states, scoring 50 out of 100 points (Transparency..., 2019). Meanwhile, neighbouring countries occupy much lower positions - Poland takes the $41^{\text {st }}$ place, while the Czech Republic - the $44^{\text {th }}$ one.

\section{Slovak Electoral System for Higher-Level Local Government}

Without citizens who support the principles of democracy and act in accordance with them, a democratic system would be dysfunctional (Mair, 2013). Important elements that affect the level of democracy are: the functioning of civil societies, stable political parties and the party system, democratic political culture (Wojtaszczyk, 1996, p. 10). A fundamental political institution in democratic countries is local government, which is in fact a form of a civil society organization.

The functioning of local government in Slovakia is regulated by various legal acts, but the constitution plays a key role as a superior legal act. In the Slovak Constitution of February 23, 2001, Articles 64 to 71 concern local government (Ústavný zákon, 90/2001 Z.z.). In July 2001, the provisions of Article 64 were supplemented with regulations regarding a higher level of local government, introducing the division of the country into 8 local government regions (kraje) from January 1, 2002 (Zákon č. 302/2001). The electoral law is regulated by the Act on Elections to Local Government Bodies (Zákon č. 303/2001). Currently, there is a transition period in Slovakia as regards the electoral law, and all regional authorities will be elected for 5 years (Zákon č. 180/2014).

Since January 1, 2002, Slovakia has been divided into 8 higher-level territorial units - self-governing regions (samosprávny kraj). The number of deputies is calculated on the basis of the number of inhabitants. Consequently, one deputy falls on 12,000 to 15,000 inhabitants. There are in total 416 deputies in Slovakia, while the detailed territorial division and number of deputies is presented in Table 1. 
Table 1. Territorial Division of Slovakia and the Number of Deputies

\begin{tabular}{|c|c|c|}
\hline $\begin{array}{c}\text { Samosprávne kraje } \\
\text { (self-governing regions) }\end{array}$ & Capital & Number of deputies \\
\hline Bratislavský & Bratislava & 50 \\
\hline Trnavský & Trnava & 40 \\
\hline Trenčiansky & Trenčín & 54 \\
\hline Nitriansky & Nitra & 57 \\
\hline Žilinský & Žilina & 49 \\
\hline Banskobystrický & Banská Bystrica & 57 \\
\hline Košický & Košice & 62 \\
\hline Prešovský & Prešov & 416 \\
\hline
\end{tabular}

Source: Author's own elaboration on the basis of http://volby.statistics.sk/osk/osk2017/sk/data03. html, 08.01.2018.

The decision-making body of the higher-level territorial unit in Slovakia is the council of the self-governing region (zastupitel'stvo samosprávneho kraja). Deputies (poslanci zastupitel'stva) are elected by universal, secret, direct and equal elections, and their term of office is 4 years.

Self-governing regions have a one-man executive body headed by its chairman (predseda samosprávneho kraja), called the župan. He or she is elected by universal, equal, direct and secret election, during the same election as representatives of local government. His or her term of office is the same as for deputies - that is, 4 years. One chairman is elected in each of seven self-governing regions.

\section{Elections and Their Results}

The sine qua non feature of democracy is free elections. As noted by Robert Dahl (1995), they are procedural requirements of democracy, because democracy, in its classic meaning, denotes above all direct participation of citizens. Seymour M. Lipset (1998) even stated that "the lack of participation and representation also reflects the non-existence of civil society and, consequently, the lack of loyalty to 
the entire system". Turnout, i.e., the percentage of people entitled to vote who go to the polls in local elections, is therefore very important for the legitimacy of power and the development of civil society. Unfortunately, in the case of local government elections in Slovakia, there was very high voter abstention until the introduction of elections to the councils of the self-governing regions - cf. Diagram 1. In 2001, the voter turnout was $26.02 \%$, in $2005-18.02 \%$, in $2009-22.90 \%$, in $2013-$ $20.11 \%$, and in $2017-29.96 \%$. It should also be observed here that a much higher voter turnout is in the parliamentary elections: in 2016 it amounted to $59.82 \%$.

Diagram 1. Turnout

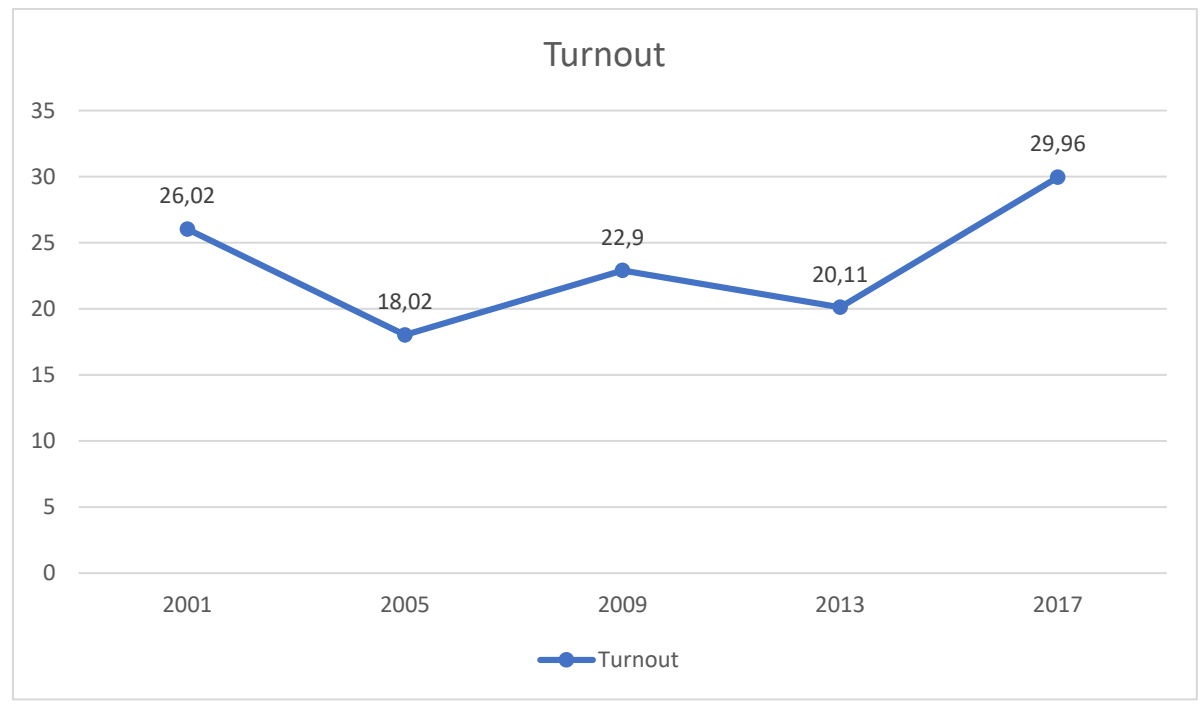

Source: Author's own elaboration on the basis of http://volby.statistics.sk/.

On November 4, 2017, elections to self-governing regions (samosprávny kraj) were held. The turnout was only $29.95 \%$ nationwide, which was the highest result at this level from the beginning of the election for the regional representation. The lowest turnout was in the Trnava Region - 24.74\%, while the highest in the Banská Bystrica Region $-40.29 \%$. Detailed data is presented in Map 1 . 
Map 1. Turnout in Self-Governing Regions

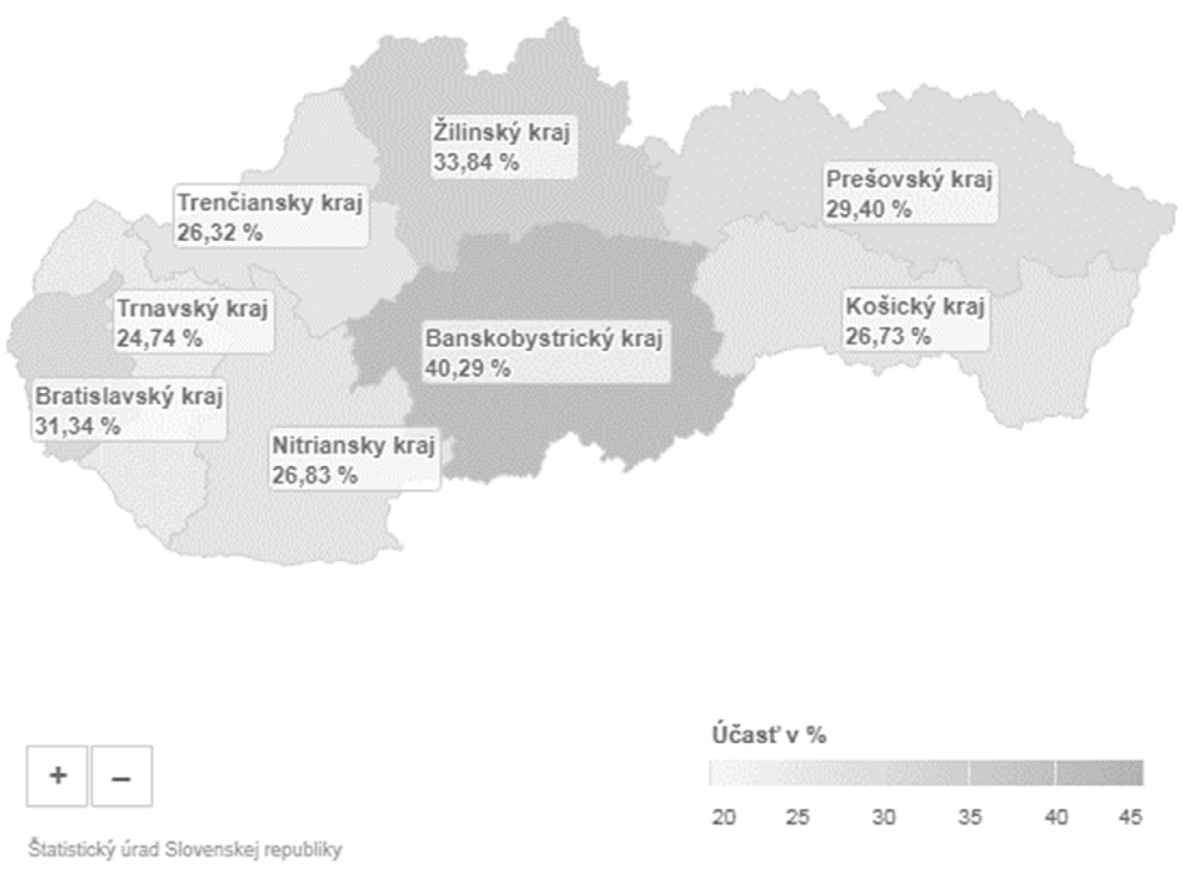

Source: http://volby.statistics.sk/osk/osk2017/sk/data01.html.

Local elections are very important because their outcome concerns matters and people that are spatially and socially close. Low turnout in local elections may indicate a problem in the functioning of local communities because these are local government elections that directly influence local community's issues. The lack of participation in elections and a low turnout reflect the actual state of civil society. A passive society, which cannot exercise its rights, is also responsible for the state and the directions of its development. There is probably a need for preventive campaigns in Slovakia, i.e., raising awareness and informing citizens about the importance of their vote. 


\section{Results of the Elections for Župans}

During the election campaigns at the regional level in Slovakia, party coalitions are formed which put forward their candidates for župans (predsedov samosprávnych krajov). It is interesting that the phenomenon of electoral regional party coalition is not found at the equivalent levels of local government in other countries of the region, i.e., in Poland, the Czech Republic, and Hungary. In the elections for župans, multi-party coalitions put out joint candidates. The very phenomenon of local government electoral coalitions in Slovakia is based on many different coalitions, different for each constituency. The largest party coalition, consisting of seven parties, was formed in the constituency of Bratislava, while the smallest, consisting of three coalition members, in Nitra. It should also be noted that some parties first formed two-party coalitions, e.g., SMK-MKP, SMER-SD, and then joined a larger coalition. At the coalition level, the SaS and OLANO parties had the most winning župans: each of them five. The ruling party in Slovakia - SMER - on the other hand, won in the coalition in only two constituencies. The detailed election results are presented in Table 2.

Table 2. Results of the Elections for Župans

\begin{tabular}{|c|c|c|c|c|}
\hline $\begin{array}{c}\text { Samosprávny kraj } \\
\text { (self-governing } \\
\text { region) }\end{array}$ & $\begin{array}{c}\text { Župan's name } \\
\text { and surname }\end{array}$ & Political parties & $\begin{array}{c}\text { \% of } \\
\text { support }\end{array}$ & $\begin{array}{c}\text { Number } \\
\text { of votes }\end{array}$ \\
\hline Bratislavský & Juraj Droba & $\begin{array}{c}\text { SaS, OBYČAJNÍ L'UDIA } \\
\text { a nezávislé osobnosti (OL'aNO), } \\
\text { SMK-MKP, NOVA, OKS, } \\
\text { Zmena zdola, DÚ }\end{array}$ & 20.42 & 36,864 \\
\hline Trnavský & Jozef Viskupič & $\begin{array}{c}\text { OBYČAJNÍ LUUIA a nezávislé } \\
\text { osobnosti (OLaNO), SaS, } \\
\text { KDH, OKS, Zmena zdola, DÚ }\end{array}$ & 42.90 & 48,584 \\
\hline Trenčiansky & Jaroslav Baška & $\begin{array}{r}\text { SMER-SD, SNS, MOST - } \\
\text { HÍD, SZ }\end{array}$ & 49.98 & 62,807 \\
\hline Nitriansky & Milan Belica & $\begin{array}{r}\text { SMER-SD, SNS, MOST - } \\
\text { HÍD }\end{array}$ & 34.10 & 52,184 \\
\hline Žilinský & Erika Jurinová & $\begin{array}{r}\text { OBYČAJNÍ LUDIA a nezávislé } \\
\text { osobnosti (OLaNO), SaS, } \\
\text { KDH, OKS }\end{array}$ & 43.67 & 82,034 \\
\hline Banskobystrický & Ján Lunter & NEKA & 48.53 & 99,169 \\
\hline
\end{tabular}


Tab. 2 - cont.

\begin{tabular}{|c|c|c|c|c|}
\hline $\begin{array}{c}\text { Samosprávny kraj } \\
\text { (self-governing } \\
\text { region) }\end{array}$ & $\begin{array}{c}\text { Župan's name } \\
\text { and surname }\end{array}$ & Political parties & $\begin{array}{c}\text { \% of } \\
\text { support }\end{array}$ & $\begin{array}{c}\text { Number } \\
\text { of votes }\end{array}$ \\
\hline Prešovský & $\begin{array}{c}\text { Milan Majer- } \\
\text { ský }\end{array}$ & $\begin{array}{c}\text { KDH, SaS, OBYČAJNÍ } \\
\text { LUDIA a nezávislé osobnosti } \\
\text { (OLaNO), NOVA }\end{array}$ & 40.36 & 72,366 \\
\hline Košický & Rastislav Trnka & $\begin{array}{c}\text { OBYČAJNÍ LUDIA a nezávislé } \\
\text { osobnosti (OLaNO), SaS, } \\
\text { KDH, NOVA, ŠANCA }\end{array}$ & 37.80 & 59,599 \\
\hline
\end{tabular}

Source: Author's own elaboration on the basis of http://volby.statistics.sk/osk/osk2017/sk/data03.html.

Analysing the election results, candidates of the party coalitions won as many as seven constituencies, while a non-party candidate in only one - in the Banská Bystrica Region (Ján Lunter). In the Bratislava Region, Juraj Droba won, receiving the lowest support of $20.42 \%$ of votes, in the Trnava Region - Jozef Viskupič (42.90\%), in the Trenčín Region - Jaroslav Baška (49.98\%), in the Nitra Region - Milan Belica (34.10\%), in the Žilina Region - Erika Jurinová (43.67\%), in the Banská Bystrica Region - Ján Lunter (48.53\%), in the Prešov Region - Milan Majerský (40.36\%), and in the Košice Region - Rastislav Trnka (37.80\% of votes).

\section{Regional Council - Local or Party Policy}

Party coalitions were also formed during elections to the councils of the self-governing regions, just as in the case of elections for presidents of the self-governing regions. Different coalitions were created in constituencies across the whole country. In order to obtain full results regarding the deputies' affiliation with the party or its lack, it is necessary to assign the data presented in the tables below to the region. 
Table 3. Number of Deputies in the Bratislava Region

\begin{tabular}{|c|c|c|c|c|c|}
\hline NEKA & $\begin{array}{c}\text { KDH, NOVA, OKS, } \\
\text { OBYČAJNÍ LUDIA } \\
\text { a nezávislé osobnosti } \\
\text { (OLaNO), SaS, } \\
\text { SMK-MKP, Zmena } \\
\text { zdola, DÚ }\end{array}$ & $\begin{array}{c}\text { STAROSTOVIA } \\
\text { A NEZÁVISLÍ } \\
\text { KANDIDÁTI, } \\
\text { MOST-HÍD, SDKÚ- } \\
\text { DS, SMER-SD, SZ, } \\
\text { SKOK-ELD }\end{array}$ & $\begin{array}{c}\text { DOMA } \\
\text { DOBRE }\end{array}$ & NF \\
\hline $\begin{array}{c}\text { Bratislavský } \\
\text { kraj }\end{array}$ & 25 & 17 & 6 & 1 & 1 \\
\hline
\end{tabular}

Source: http://volby.statistics.sk/osk/osk2017/sk/data03.html.

Table 3 shows the results for the Bratislava Region, where independent candidates won 25 seats, while the coalition of $\mathrm{KDH}$, NOVA, OKS, OBYČAJNÍ L'UDIA a nezávislé osobnosti (OL'aNO), SaS, SMK-MKP, Zmena zdola, DÚ secured 17 seats, the coalition of STAROSTOVIA A NEZÁVISLÍ KANDIDÁTI MOST-HÍD, SDKÚ-DS, SMER-SD, SZ, SKOK-ELD 6 seats, and DOMA DO$\mathrm{BRE}$ and NF one each. In total, there were as many non-party as party candidates in this region so the degree of politicisation is $50 \%$.

Table 4. Number of Deputies in the Trnava Region

\begin{tabular}{|c|c|c|c|c|c|}
\hline & NEKA & MOST-HÍD & $\begin{array}{c}\text { KDH, OKS, } \\
\text { OBYČAJNÍ LUDIA } \\
\text { a nezávislé osobnosti } \\
\text { (OLaNO), SaS, Zmena } \\
\text { zdola, DÚ }\end{array}$ & $\begin{array}{c}\text { SMK- } \\
\text {-MKP }\end{array}$ & $\begin{array}{c}\text { SMER- } \\
\text {-SD }\end{array}$ \\
\hline $\begin{array}{c}\text { Trnavkký } \\
\text { kraj }\end{array}$ & 14 & 1 & 11 & 13 & 1 \\
\hline
\end{tabular}

Source: http://volby.statistics.sk/osk/osk2017/sk/data03.html.

In the Trnava constituency, as shown in Table 4, independent candidates received 14 seats, the MOST-HÍD coalition - 1 seat, the KDH, OKS, OBYČAJNÍ LUDIA a nezávislé osobnosti (OL'aNO), SaS, Zmena zdola, DÚ coalition 11 seats, SMK-MKP 13 seats, and SMER-SD only one seat. To sum up, party candidates won as many as 26 seats. The level of politicisation in local politics in the Trnava Region is as much as 64\%. 
Table 5. Number of Deputies in the Trenčín Region

\begin{tabular}{|c|c|c|c|}
\hline & NEKA & $\begin{array}{c}\text { MOST-HÍD, } \\
\text { SNS, SMER-SD, } \\
\text { SZ }\end{array}$ & $\begin{array}{c}\text { KDH, NOVA, OKS, } \\
\text { OBYČAJNÍ LUDIA a nezávislé } \\
\text { osobnosti (OLaNO), SaS, } \\
\text { Zmena zdola, DÚ }\end{array}$ \\
\hline $\begin{array}{c}\text { Trenčiansky } \\
\text { kraj }\end{array}$ & 22 & 16 & 9 \\
\hline
\end{tabular}

Source: http://volby.statistics.sk/osk/osk2017/sk/data03.html.

Table 5 shows the results in the Trenčin Region, where independent candidates won 22 seats, the coalition of MOST-HÍD, SNS, SMER-SD, SZ gained 16 seats, while the coalition of KDH, NOVA, OKS, OBYČAJNÍ L'UDIA a nezávislé osobnosti (OLaNO), SaS, Zmena zdola, DÚ took 9 seats. Party candidates altogether won 25 seats. The percentage of the seats secured by the party election committees was $53 \%$.

Table 6. Number of Deputies in the Nitra Region

\begin{tabular}{|c|c|c|c|c|c|}
\hline & NEKA & $\begin{array}{c}\text { LS Naše } \\
\text { Slovensko }\end{array}$ & $\begin{array}{c}\text { MOST-HÍD, } \\
\text { SNS, SMER-SD }\end{array}$ & $\begin{array}{c}\text { KDH, NOVA, OKS, } \\
\text { OBYČAJNÍ LUDIA } \\
\text { a nezávislé osobnosti } \\
\text { (OL’aNO), SaS, ŠANCA }\end{array}$ & $\begin{array}{c}\text { SMK- } \\
\text { MKP }\end{array}$ \\
\hline $\begin{array}{c}\text { Nitriansky } \\
\text { kraj }\end{array}$ & 15 & 1 & 17 & 10 & 11 \\
\hline
\end{tabular}

Source: http://volby.statistics.sk/osk/osk2017/sk/data03.html.

In the Nitra Region (see Table 6), independent candidates won only 15 seats, while party candidates took a total of 39 seats, including L'S Naše Slovensko 1 seat, MOST-HIID, SNS, SMER-SD - 17 seats; the coalition of KDH, NOVA, OKS, OBYČAJNÍ LUDIA a nezávislé osobnosti (OLaNO), SaS, ŠANCA 10 seats, while the coalition of SMK-MKP - 11. The level of politicisation in the Nitra Region was as high as $72 \%$. 
Table 7. Number of Deputies in the Žilina Region

\begin{tabular}{|c|c|c|c|c|}
\hline NEKA & SNS & SMER-SD & $\begin{array}{c}\text { KDH, NOVA, OKS, } \\
\text { OBYČAJNÍ LUDIA a nezávislé } \\
\text { osobnosti (OLaNO), SaS }\end{array}$ \\
\hline $\begin{array}{c}\text { Žilinský } \\
\text { kraj }\end{array}$ & 25 & 5 & 10 & 17 \\
\hline
\end{tabular}

Source: http://volby.statistics.sk/osk/osk2017/sk/data03.html.

Table 7 shows the results of the elections in the Žilina Region. Non-party candidates won 25 seats there, while party candidates: from the SNS party - 5 seats, the SMER-SD coalition - 10 seats, and the coalition of KDH, NOVA, OKS, OBYČAJNÍ L'UDIA a nezávislé osobnosti (OLaNO), and SaS - 17 seats. The percentage of the seats taken by the party election committees was $56 \%$.

Table 8. Number of Deputies in the Banská Bystrica Region

\begin{tabular}{|c|c|c|c|c|c|c|c|}
\hline NEKA & $\begin{array}{c}\text { L'S Naše } \\
\text { Slovensko }\end{array}$ & $\begin{array}{c}\text { MOST- } \\
\text {-HÍD }\end{array}$ & SNS & $\begin{array}{c}\text { SMER- } \\
\text {-SD }\end{array}$ & $\begin{array}{c}\text { SMK- } \\
\text {-MKP }\end{array}$ & $\begin{array}{c}\text { KDH, NOVA, OKS, } \\
\text { OBYČAJNÍ LUDIA } \\
\text { a nezávislé osobnosti } \\
\text { (OLaNO), SaS }\end{array}$ \\
\hline $\begin{array}{c}\text { Bansko- } \\
\text { bystrický } \\
\text { kraj }\end{array}$ & 22 & 1 & 1 & 1 & 15 & 5 & 4 \\
\hline
\end{tabular}

Source: http://volby.statistics.sk/osk/osk2017/sk/data03.html.

Table 8 presents the results of the elections in the Banská Bystrica Region, where independent candidates won 22 seats, while party candidates -27 seats, the majority of which were taken by the SMER-SD coalition (15), while the SMK-MKP coalition picked up 5 seats. The level of local government politicisation is 55\%.

Table 9. Number of Deputies in the Prešov Region

\begin{tabular}{|c|c|c|c|c|c|}
\hline & NEKA & SNS & SMER-SD & ÚSVIT & $\begin{array}{c}\text { KDH, NOVA, OBYČAJNÍ LUDIA } \\
\text { a nezávislé osobnosti (OLaNO), SaS }\end{array}$ \\
\hline $\begin{array}{c}\text { Prešovský } \\
\text { kraj }\end{array}$ & 22 & 2 & 16 & 1 & 21 \\
\hline
\end{tabular}

Source: http://volby.statistics.sk/osk/osk2017/sk/data03.html. 
Table 9 shows the results of the elections in the Prešov Region, where independent candidates won 22 seats, while as many as 40 seats were secured by party candidates. As far as the latter groups is concerned, the coalition of $\mathrm{KDH}$, NOVA, OBYČAJNÍ L'UDIA a nezávislé osobnosti (OL'aNO) and SaS gained the most seats, as many as 21 . The percentage of the seats secured by the party election committees is $65 \%$.

Table 10. Number of Deputies in Košice Region

\begin{tabular}{|c|c|c|c|c|c|c|c|}
\hline NEKA & $\begin{array}{c}\text { MOST- } \\
\text {-HÍD }\end{array}$ & $\begin{array}{c}\text { SMER- } \\
\text {-SD }\end{array}$ & $\begin{array}{c}\text { SMK- } \\
\text {-MKP }\end{array}$ & ŠKV & $\begin{array}{c}\text { KDH, NOVA, OBYČAJ- } \\
\text { NÍ LUDIA a nezávislé } \\
\text { osobnosti (OLaNO), SaS }\end{array}$ & $\begin{array}{c}\text { SMK- } \\
\text {-MKP }\end{array}$ \\
\hline $\begin{array}{c}\text { Košický } \\
\text { kraj }\end{array}$ & 16 & 6 & 1 & 16 & 1 & 16 & 1 \\
\hline
\end{tabular}

Source: http://volby.statistics.sk/osk/osk2017/sk/data03.html.

Table 10, in turn, shows the results of the elections in the Košice Region, in which independent candidates won only 16 seats, while party ones took 41 seats. The largest number of seats among political parties was gained by the coalitions of SMK-MKP, and KDH, NOVA, OBYČAJNÍ LUDIA a nezávislé osobnosti (OLaNO), $\mathrm{SaS}$ - each coalition won 16 seats. The politicisation of local politics in this region is $72 \%$.

Table 11. List of Party and Non-Party Councillors in the Regions

\begin{tabular}{|c|c|c|c|}
\hline $\begin{array}{c}\text { Samosprávny kraj } \\
\text { (self-governing region) }\end{array}$ & $\begin{array}{c}\text { Non-party } \\
\text { deputies/councillors }\end{array}$ & $\begin{array}{c}\text { Party deputies/ } \\
\text { councillors }\end{array}$ & $\begin{array}{c}\text { Percentage } \\
\text { of politicisation }\end{array}$ \\
\hline Bratislavský & 25 & 25 & $50 \%$ \\
\hline Trnavský & 14 & 26 & $64 \%$ \\
\hline Trenčiansky & 22 & 25 & $53 \%$ \\
\hline Nitriansky & 15 & 39 & $72 \%$ \\
\hline Žilinský & 25 & 32 & $56 \%$ \\
\hline Banskobystrický & 22 & 27 & $55 \%$ \\
\hline Prešovský & 22 & 40 & $65 \%$ \\
\hline Košický & 16 & 41 & $72 \%$ \\
\hline In total & 161 & 255 & $61 \%$ \\
\hline
\end{tabular}

Source: http://volby.statistics.sk/osk/osk2017/sk/data03.html. 
When analysing the total number of non-party and party deputies, we see that there are more party deputies (255) than non-party ones (161), as shown in Table 11. The most politicised regions are the Košice Region (as much as 72\%), which has 41/57 party deputies, and the Nitra Region with 39/54 party deputies. Independent councillors do not hold the majority in any region, only in the Bratislava Region the number of independent and party deputies is equal and amounts to 25, thus the level of politicisation is $50 \%$.

Taking into account the total number of the seats won by specific political parties and coalitions, SMER-SD received the most seats - 58, the coalition of MOSTHIID, SNS, SMER-SD, SZ came in second, receiving 37 seats, and the third was the SMK-MKP coalition with 30 seats.

\section{Conclusion}

According to the quantitative analysis of the results of regional government elections in Slovakia, there is a high level of politicisation of self-governing regions, which amounts to $61 \%$ on the national scale. Competition between political parties at the level of regional government reflects the positions of these groups on the central political scene, taking into account the parliamentary elections of 2016. Accordingly, SMER-SD won $28.28 \%$ of votes in the parliamentary elections, OLaNO-NOVA $11.02 \%, \mathrm{KDH}-4.94 \%, \mathrm{SaS}-12.10 \%$, and SMK-MKP $-4.04 \%$, which translated into the results of local elections: SMER-SD introduced the most deputies - 58, and the coalition KDH, NOVA, OBYČAJNÍ LUDIA a nezávislé osobnosti (OLaNO), $\mathrm{SaS}$ came second with 37 deputies, while the coalition of SMK-MKP noted a significant increase in support in local elections, introducing as many as 30 deputies.

It is also worth emphasising another problem, which is low voter turnout. High absenteeism may indicate a poor condition of civil society and representative democracy. Empowering local and regional authorities can have many negative effects. Besides, political corruption can often occur in this situation, defined as corrupt activities involving government officials.

Political parties do not affect the legitimacy of democracy at the local level and should not be treated as part of civil society, while the central party's imposition of its vision on the local level provokes a struggle for power, which results in a lack of cooperation between inhabitants and local authorities, and failure to meet the needs of the local community (Gąciarz, 2004, pp. 72-74). Undoubtedly, local government is one of the pillars of civil society and the most important form of public administration decentralisation in a modern democratic state (Tusiński, 2016, p. 33). 
Social and political passivity of citizens means that certain group interests are not articulated and advanced, and thus no civil society institutions are created. It is also worth noting that the fewer civil society institutions and active citizens working for the community, the easier it is for parties to exercise power. It seems that the proper functioning of civil society in Slovakia has been disturbed, as there are neither mechanisms for ensuring social balance and civic culture, nor cooperation between the government and the third sector.

\section{References:}

2019 Report on the State of Civil Society in the EU an Russia (2020) [online]. Retrieved from: https://eu-russia-csf.org/wp-content/uploads/2020/01/20200116_RU-EU_Report2019_online_covers.pdf.

Barański, M., \& Czyż, A. (2005). Słowacja. In: M. Barański (Ed.). Systemy polityczne państw Europy Środkowej i Wschodniej. Ustrój, organy wtadzy, partie polityczne (p. 380). Katowice: Wydawnictwo Uniwersytetu Śląskiego.

Bútora, M., Bútorová, Z., \& Strečanský B. (2012). Aktivne občianstvo a mimovládny sektor na Slovensku. Trendy a perspektívy. Bratislava: Včelí dom. Rerieved from: .

Císař, O., Linek, L., \& Vráblíkova, K. (2017). Úvod. In: L. Linek, O. Císař, I. Petrúšek, \& K. Vráblíkova (Eds.). Občanstvi a politická participace v České republice (pp. 8-22). Praha: Sociologickě Nakladatelství (SLON).

Dahl, R. (1995). Demokracja i jej krytycy. Kraków: Aletheia.

Frič, P. (2016). Úvodní poznámky. In: P. Frič (Ed.). Občanský sektor v ohroženi? (pp. 13-33). Praha: Sociologickě Nakladatelství (SLON).

Gąciarz, B. (2004). Instytucjonalizacja samorządności. Aktorzy i efekty. Warszawa: Instytut Filozofii i Socjologii Polskiej Akademii Nauk.

Gbúrová, M., Dobiaš, D., \& Geffert, R., Onufrák, A., Bzdilová, R., Eštok, G., Gojdič, P., \& Hrehová, M. (2015a). K problematike spravodlivosti a rovnosti v kontexte občianskej spoločnosti. Košice: Univerzita Pavla Jozefa Šafárika v Košicach.

Gbúrová, M. Koziak, T., Dobiaš, D., Šutajová, J., Onufrák, A., Eštok, G., \& Bzdilová, R. (2015b). Základny politológie. Košice: Univerzita Pavla Jozefa Šafárika v Košicach. Gendźwiłł, A., \& Żółtak, T. (2012). Bezpartyjność w powolnym odwrocie. Analiza rozpowszechniania bezpartyjności w wyborach lokalnych w Polsce w latach 2002-2010. Studia regionalne i lokalne, 1, 102-121.

Kancik-Kołtun, E. (2017a). Władze miast: między partyjnością a bezpartyjnością. Samorzad Terytorialny, 12, 42-51.

Kancik-Kołtun E. (2017b). E-marketing terytorialny. Teoria i praktyka. Lublin: Wydawnictwo Uniwersytetu Marii Curie-Skłodowskiej.

Krajniak, I.M. (2015). Banda zlodejov: Šokujúca pravda o oligarchoch a politikoch na Slovensku. Bratislava: Kniha do ucha, s. r. o. 
Lipset, S.M. (1998). Homo politicus. Spoteczne podstawy polityki. Warszawa: Wydawnictwo Naukowe PWN.

Mair, P. (2013). Ruling the Void: The Hollowing of Western Democracy. London: Verso.

Sasinowski, H. (2012). Społeczeństwo obywatelskie i jego rola w budowie demokracji. Ekonomia i Zarządzanie, 4(1), 30-47.

Štatistický úrad Slovenskej republiky. Retrieved from: http://volby.statistics.sk/.

Strečanský, B. (2015). Civil Society in Slovakia. In: Ch. Schreier (Eds.). 25 Years After: Mapping Civil Society in the Visegrád Countries (pp. 59-108). Stuttgart: Lucius et Lucius Verlagsgesselschaft mbH Stuttgart.

Szymczak, W. (2007). Znaczenie wartości w tworzeniu społeczeństwa obywatelskiego. In: E. Balawajder (Ed.). Spoteczeństwo obywatelskie. Modele teoretyczne i praktyka spoteczna (pp. 27-45). Lublin: Wydawnictwo Katolickiego Uniwersytetu Lubelskiego im. Jana Pawła II.

Transparency International the Global Coalition against Corruption (2019). Corruption Perceptions Index. Retrieved from: https://www.transparency.org/en/cpi/2019/ results/svk.

Tusiński, P.A. (2016). Prawne narzędzia upolitycznienia samorządu terytorialnego jako przeszkody w budowaniu społeczeństwa obywatelskiego w III RP. In: S. Michałowski, M. Sidor, \& J. Wasil (Eds.). 25 latsamorzadu terytorialnego w Polsce-bilans doświadczeń (pp. 33-63). Lublin: Wydawnictwo Uniwersytetu Marii Curie-Skłodowskiej.

Ústavný zákon, 90/2001 Z.z., z 23. februára 2001, ktorým sa mení a dopĺňa Ústava Slovenskej republiky č. 460/1992 Zb. v znení neskorších predpisov.

Ware, A. (1996). Political Parties and Party Systems. Oxford: Oxford University Press.

Wojtaszczyk, K.A. (1996). Transformacja ustrojowa w krajach Europy Wschodniej, Środkowej i Południowej. In: E. Zieliński (Ed.). Transformacja ustrojowa państw Europy Środkowej $i$ Wschodniej (pp. 9-20). Warszawa: Dom Wydawniczy Elipsa.

Zákon č. 180/2014 Z. z. Zákon o podmienkach výkonu volebného práva a o zmene a doplnení niektorých zákonov.

Zákon č. 302 zo 6. júla 2001 Z.z. o samospráve vyšších územných celkov (zákon o samosprávnych krajoch) v znení neskorších predpisov. Retrieved from: http://www.zakonypreludi.sk/zz/2001-302.

Zákon č. 303/2001 Z.z. Zákon zo 4. júla 2001 o vol'bách do orgánov samosprávnych krajov a o doplnení Občianskeho súdneho poriadku. Retrieved from: http://www.noveaspi.sk/products/lawText/1/51660/1/2. 